\title{
Baltijos valstybès: ginklų prekybos tarpininkai ir nelegalus ginklų gabenimas
}

\begin{abstract}
Nelegali prekyba ginklais, strateginemis ir dvigubos paskirties prekemis pasibaigus šaltajam karui labai traukia tarptautinès visuomenès dèmesị. Ypatingas dėmesys skiriamas priemonèms, kuriomis siekiama užkirsti kelią nelegaliam ginklu gabenimui iš teisètos rinkos i , ,juodają". Šio straipsnio centre - ginklu prekybos tarpininkai, padedantys neteisètai gabenti ginklus. Trumpai aptarus tarpininkų vaidmenį konkurencinèje teisètoje ginklų rinkoje, bus nagrinejama tamsioji ginklų prekybos tarpininkų veiklos pusè. Po to bus aptarti du su Baltijos šalių piliečiais susiję atvejai, kurie parodo, kokiu būdu ginklu prekybos tarpininkai veikia iš i̇vairių vietų, panaudoja korumpuotus valstybės pareigūnus, fiktyvias bendroves, patogių šaliu vèliavas ir aplinkinius maršrutus, kur silpna muitu ir pasienio kontrolè, kad aprūpintų „nepageidaujamus tiesioginius naudotojus“. Baltijos valstybiu galimybès transporto paslaugų srityje, susijusios su tarpininkavimo veikla, taip pat bus aptartos.

Baltijos valstybės yra tarp nedaugelio šalių, jau turinčiu ịstatymų, kurie apibūdina, kontroliuoja ir reglamentuoja tarpininkavimo veiklą. Tačiau norint užkirsti kelią nelegaliam ginklų gabenimui, nepakanka atskirų valstybių kontrolès - reikia bendradarbiauti tarptautiniu mastu.

Straipsnyje aptariami Baltijos valstybėms šioje srityje kylantys iššūkiai, taip pat Baltijos valstybių iššūkiai tradiciniam mąstymui, kalbant apie tarptautinius ginklų neplatinimo režimus. Straipsnis baigiamas klausimu - koks yra Baltijos valstybių vaidmuo kovojant su ginklų gabenimu iš teisètų rinkų ị neteisètas ir kontroliuojant ginklų prekybos tarpininkus?
\end{abstract}

\section{Ivadas}

Pasibaigus šaltajam karui mūsų nuomonę apie prekybą ginklais apskritai ir ypač neteisètą prekybą paveikè daug veiksnių. Pavyzdžiui, atsirado daug bendro pobūdžio aplinkybių, tokių kaip dideli sienų reikšmès ir funkcijų pokyčiai, valstybiu iširimas ir integracija, kriminalinès veiklos ir konfliktų skirtumų supanašèjimas ir pastebimas tarptautinès prekybos masto padidèjimas. Be to, tyrinètojų, nevalstybiniu organizacijų ir vyriausybių požiūris ị juodosios rinkos problemas, susijusias su ginklais, karine ịranga, strateginėmis bei dvigubos paskirties prekėmis ir kitais instrumentais, naudojamais žudyti ir žmogaus teisèms pažeisti, gerokai pakito. Reikètu pažymèti, kad sprendžiant juodosios rinkos problemas trukdymas gabenti ginklus iš teisètos tarptautinių ginklų rinkos i juodają turètų tapti prioritetu. Tai savo ruožtu

"Dr. Paul Holtom - Glamorgano universiteto Pasienio studijų centro mokslo darbuotojas. Adresas: Pontypridd, Wales, CF371DL, UK. Tel. +44 1443654174, el. paštas: pholtom@glam.ac.uk 
paskatino kreipti daugiau dèmesio į veiklą tų ịmonių ir asmenų, kurie daugelị metụ veikè „pilkosiose zonose“ pasinaudodami teisètos ginklu prekybos spragomis ir padẻdami vyriausybėms slapta pervežti ginklus tarptautiniu mastu „,nepageidaujamiems“ sukilèliams ir tiesioginiams naudotojams. Šie asmenys ir įmonès dažnai vadinami „tarpininkais“, „perpardavejais“, „,makleriais“ ir dar kitaip.

Šiame straipsnyje vartosiu terminą „,ginklų prekybos tarpininkai“, jų veikla bus detaliau aptarta kitoje dalyje. Jame siekiama akcentuoti kai kuriuos ginklų prekybos tarpininkų keliamus Baltijos valstybėms iššūkius ir atsakus i juos, kurių ėmèsi ir galètų imtis susijusios su Estijos, Latvijos ir Lietuvos eksporto kontrolės sistemomis vyriausybès ir institucijos, siekdamos neleisti, kad ginklai ir ịranga iš teisètos ginklų rinkos patektų i neteisètą. Naudodamiesi argumentais, pateiktais Latvijos gynybos ministro, pirmojoje straipsnio dalyje išnagrinèsime ginklų prekybos tarpininkų panaudojimo teisètoje ginklų rinkoje logiką, o po to aptarsime problemas, susijusias su ginklų prekybos tarpininkų gebejjimu veikti legaliose „pilkosiose zonose“, padèti gabenti ginklus neteisètiems tiesioginiams naudotojams, apgaudinèti silpnas eksporto ar importo sistemas turinčias valstybes ir „maitinti“ korumpuotus valstybės pareigūnus (bei leisti jiems maitintis).

Panaudosime du klasikinius tarpininkavimo neteisètai gabenant ginklus atvejus, susijusius su Baltijos valstybių piliečiais; pademonstruosime metodus, kuriuos naudoja ginklų prekybos tarpininkai, noreddami parduoti ginklus organizuotoms nusikaltèlių grupuotėms ir valstybėms, kurioms paskelbtas Jungtinių Tautų embargas, îtraukti ị šią veiklą korumpuotus valstybès pareigūnus, apeiti silpnas kontrolès sistemas; aptarsime laiko tarpsnị, reikalingą korumpuotam ginklų prekybos tarpininkui nuteisti, ir tarptautinio bendradarbiavimo svarbą keičiantis informacija bei derinant tyrimus, atliekamus valstybių viduje ir už jų ribų. Šie atvejai iš dalies paskatino Baltijos valstybes priimti ịstatymus dẻl ginklų prekybos tarpininkų veiklos anksčiau už ,senąsias“ Europos Sajungos valstybes nares. Paskutinèje šio straipsnio dalyje aptarsime Baltijos valstybiu ginklų prekybos tarpininku veiklos kontrolés metodus, parodysime tarptautinio bendradarbiavimo svarbą siekiant sèkmingai įgyvendinti šioje srityje valstybès ịstatymus. Taip pat atkreipsime dẻmesị i iššǔkius ir problemas, susijusias su tarpininkavimo kontrolès būdų taikymu Baltijos valstybėse ir kitur.

\section{Ginklų prekybos tarpininkai ir nelegalios ginklų prekybos metodai}

Ginklų prekybos tarpininkai yra asmenys, kurie organizuoja ginklų gabenimą tarp dviejų arba daugiau šalių ir, norèdami sudaryti sandèrị, padeda susitikti pirkèjams, pardavëjams, vežèjams, finansininkams ir draudejams. Paprastai jie taip elgiasi dèl finansinès naudos, nors politiniai ir religiniai motyvai taip pat gali turèti ịtakos kai kuriems sandèriams. Tarpininkai dažnai negyvena toje šalyje, iš kurios yra siunčiami ginklai. Jie taip pat negyvena šalyse, per kurias ginklai gabenami, arba tose, kurioms jie skirti. Dẻl to tokios „trečiosios šalies“ ginklų prekybos tarpininkų veiklą ypač sunku nustatyti, stebèti ir kontroliuoti. Ginklų prekybos tarpininkai dirba išvien su transporto ir gabenimo agentais. Šie agentai sudaro sutartis su transporto 
bendrovėmis, vežejais ir ekipažais dèl ginklų siuntų gabenimo jūra, oru, geležinkeliais ir keliais ${ }^{1}$.

Taikos fondo Ginklų ir konfliktų programos direktoriaus Kathiso Austino nuomone, daugelis pasaulio vyriausybių ir sąžiningų ginklų gamybos bendrovių patiki ginklų prekybos tarpininkams reklamuoti savo ginklus bei padeti organizuoti ir palengvinti jų pardavimą ${ }^{2}$. Atrodo, kad pasaulio ginklų rinkoje, kuri po šaltojo karo tampa vis konkurencingesne, jie jau rado pelningą nišą. Latvijos dienraštis „Diena“ $2004 \mathrm{~m}$. išspausdino daug straipsnių apie tarpininkų, padejjusių aprūpinti ginklais Latvijos kariuomenę, vaidmenị. Juose buvo tvirtinama, kad tarpininkai teikia vertingą paslaugą ir gali pasiūlyti geresnes kainas už tas, kurios būna perkant tiesiai iš gamintojų ${ }^{3}$.

Be to, straipsniuose teigiama, kad 2002-2003 m. Latvijos krašto apsaugos ministerija pirko ginklų iš devynių negaminančiu ginklų Latvijos bendrovių už 1,14 $\mathrm{mln}$. latų (1,73 mln. eurų/2 mln. JAV dolerių) iš bendros $1,3 \mathrm{mln}$. latų sumos ( $2 \mathrm{mln}$. eurų/2,4 mln. JAV dolerių), tais metais išleistos ginklams įsigyti. Likusioji pinigu dalis buvo skirta ginklams tiesiai iš užsienio gamintojų pirkti.

„Dienos“ straipsniuose abejojama, ar galima pasitikèti Latvijos tarpininkais dèl kelių priežasčių. Pirma, teiginiu, kad tarpininkų kainos mažesnès negu gamintojų, viename straipsnyje abejoja ir Latvijos korupcijos tyrimo specialistas, nors tvirtinama, jog tarpininkais pasinaudojama tik pateikiant nedidelius užsakymus (pvz., granatoms, šoviniams), o dideli ginklų sistemų užsakymai atliekami tarpvalstybiniu lygmeniu ${ }^{4}$. Antra, straipsnyje, parašytame $2004 \mathrm{~m}$. vasario mėn., pažymima, kad konkursai buvo viešai skelbiami tik Latvijos vyriausybės laikraštyje „Latvijas Vestnesis“ ir Krašto apsaugos ministerijos bei Pirkimų priežiūros tarnybos (IUB) interneto tinklalapiuose, todèl dauguma firmų, konkuruojančių dèl paraiškų, buvo smulkūs Latvijos tarpininkai. Nuo 2004 m. rugpjūčio mèn. IUB nebeskelbia karinių pirkimų savo tinklalapyje, o Latvijos krašto apsaugos ministerija neprašo pateikti paraiškų ir neskelbia, kas jas pateiks. Pirkimų neskaidrumą, kaip problemų ir galimos korupcijos šaltini, taip pat nurodo Lietuvos analitikai ${ }^{5}$. Nepaisant to, galbūt daugiausia abejonių „Dienos“ straipsniuose kelia tas faktas, kad Estijos ir Lietuvos kariuomenès perka ginkluotę tiesiai iš gamintojų arba per tarpvalstybinius karinio bendradarbiavimo susitarimus. Nė viena iš šių šalių nesinaudoja nei vietinių, nei užsienio tarpininkų paslaugomis. Jei pirkti ginkluotę šitaip

\footnotetext{
${ }^{1}$ BASIC, International Alert \& Saferworld, „Controlling arms brokering and transport agents: Time for international action“, Briefing 8: Biting the Bullet, 2001, http://www.international-alert.org/pdf/ pubsec/btb_brf8.pdf, 20040526.

${ }^{2}$ Austin K., „Illicit Arms Brokers: Aiding and Abetting Atrocities“, The Brown Journal of World Affairs, 9 (1), 2002, p. 205.

3 Žr., pvz.: Krastinš J. \& Petersons K., „Ieroči armijai no Jelgavas un Rīgas“, Diena web-site, 2004 02 24. http://www.diena.lv, 200501 13; Krastinš J., „Ieroču iepirkumi ar klusinātāju“, Diena vebsite, 200409 09, http://www.diena.lv, 20050113.

${ }^{4}$ „Valdība sāk ieroču iegādi“, Diena web-site, 200406 10, http://www.diena.lv, 20050113.

${ }_{5}^{5}$ Gricius A. \& Paulauskas K., „Democratic Control over the Armed Forces in Lithuania”, Lithuanian Strategic Review 2002, Vilnius, 2003, p. 247; „Lithuanian Defence Spending is not fully transparent“, BBC Monitoring Report, 200410 21, paimta iš dienraščio Kauno diena, 2004 spalio 20 d., p. $1-9$.
} 
yra iš tiesų pigiau, tai argi nestebina tas faktas, kad Latvijos kaimynès nesinaudoja vietinių tarpininkų paslaugomis? Kodèl jų ryšiai su užsienio tiekejjais geresni? Bet galbūt svarbiausia, kad problema, neịvardyta „Dienos“ straipsnyje, yra ta, jog ginklų prekybos tarpininkų veikla ir jos principai kelia vis daugiau įtarimų ir abejonių.

Atsakymas ị paskutinị klausimą yra gana paprastas. İtariama, kad daugelis nesąžiningų ginklų prekybos tarpininkų tiekia ginklus valstybėms, kurioms paskelbtas Jungtinių Tautų, Europos saugumo ir bendradarbiavimo organizacijos ir Europos Sajungos embargas, teroristams ir sukilèliams, organizuotoms nusikaltèlių grupuotèms ir kitiems „nepageidaujamiems“ tiesioginiams naudotojams ir agentams, kurie ịtariami naudojantys ginklus, karinę įrangą, kankinimo įrankius ir pavojingas medžiagas nepageidaujamiems tikslams. Tokios pavardès kaip Viktoras Boutas, Wilhelmas Ehlersas ir Sarkisas Soghanalianas suteikè ginklų prekybos tarpininkams nepatrauklias ,prekiautojų mirtimi“ pravardes, Austino nuomone, dèl to, kad jie „iš esmès atsakingi už smurto konfliktų aštrinimą, terorizmo rèmimą, nusikalstamumo didinimą ir Jungtinių Tautų ginklų embargo pažeidimą"6.

Nors šiuo metu nèra teisiškai įpareigojančių tarptautinių nuostatų ir sutarčių dèl ginklų gabenimo ir dèl to tarptautinèje teisèje griežtai nenustatyta, kas yra teisèta ir neteisèta ginklų prekyba arba vežimas, šalių eksporto kontrolès ịstatymai, Jungtinių Tautų, Europos Sajungos ir Europos saugumo ir bendradarbiavimo organizacijos remiamas ginklų embargas ir ịvairios tarptautinès nuostatos dèl ginklų neplatinimo tam tikru mastu leidžia atskirti neteisètą ir teisètą ginklu gabenimą ir rinkas ${ }^{7}$. Manoma, kad ginklų prekybos tarpininkai vaidina pagrindinị vaidmenị gabenant ginklų siuntas, iš pažiūros atitinkančias eksportuojančių bei importuojančių šaliu įstatymus ir kontrolès sistemas, bei perduodant ginklų siuntas i rankas asmenims, grupėms, judejimams ir armijoms, kuriems jie nebuvo skirti ir kuriems paprastai neleidžiama pirkti ginklų teisètose tarptautinèse ginklų rinkose. Arba kitais atvejais nustatoma, kad tarpininkai prekiauja ginklais ir/ arba medžiagomis, kurių neleidžiama parduoti tarptautinejje ginklų rinkoje. Kitaip tariant, manoma, jog ginklų prekybos tarpininkų vaidmuo yra svarbus ne tik teisètoje ginklų rinkoje, jis tampa lemiamas gabenant ginklus iš teisètos rinkos i neteisètą. Taip pat įtariama, kad jie padeda vyriausybėms atlikti slaptą, arba „pilkajį “, ginklų gabenimą ${ }^{8}$.

Problema, su kuria susiduria pareigūnai, atsakingi už eksporto kontrolès režimo taikymą ir užtikrinimą, kad ginklų siuntas gautų registruoti tiesioginiai naudotojai, yra ta, jog dèl ginklų prekybos tarpininkų nepaprastų sugebejimų sunku nutraukti neteisètą ginklų gabenimą ar netgi nustatyti, kurioje maršruto vietoje ginklai nukreipiami „nepageidaujamam“/nenustatytam tiesioginiam naudotojui. Brianas Woodas

\footnotetext{
${ }^{6}$ Austin K., (2 išnaša), p. 204.

${ }^{7}$ Gillard E.-C., „What's Legal? What's Illegal?“, Lumpe L., red., Running Guns: The Global Black Market in Small Arms, London: Zed Books, 2000, p. 27-52.

${ }^{8}$ Marsh N., „Two Sides of the Same Coin? The Legal and Illegal Trade in Small Arms“, The Brown Journal of World Affairs, 9 (1), 2002, p. 221-3; Mathiak L. \& Lumpe L., „Government GunRunning to Guerillas“, Lumpe L., red., Running Guns: The Global Black Market in Small Arms, London: Zed Books, 2000, p. 55-80.
} 
ir Johnas Pelemanas, garsūs ekspertai, tiriantys tarpininkavimą prekybos ginklais srityje, nustate, kad „pervežimų agentai ir ginklų prekybos tarpininkai, siekdami ịkurti sudètingus tarptautinius tinklus, imasi bet kokių priemonių, įtraukdami daugybę subrangovų, fiktyvių bendrovių, bei naudoja aplinkinius transporto maršrutus $^{\text {“9 }}$. Tarpininkavimo prekybos ginklais srityje tyrimai rodo, kad vežimų agentai, ekspeditoriai, finansininkai, draudejjai ir netgi vyriausybių pareigūnai sąmoningai ir nesąmoningai padeda sukurti daugybę dokumentų, padedančiu nuslèpti nelegalų ginklu gabenimą. Dèl to tikètina, kad ilgi aplinkiniai maršrutai, kertantys daugelio valstybių sienas, naudojami norint palengvinti neteisètai gabenti ginklus, jog gabenant pavienę nelegalią ginklų siuntą yra naudojamas toliau aprašytų metodų derinys.

Siunta gali:

- tam tikrame etape būti kontrabanda pervežama per sieną, nedeklaruojant krovinio muitinès pareigūnams, arba galbūt muitininkai ir/arba pasieniečiai yra papirkti, kad „nepastebètu“ krovinio turinio;

- turèti ne tas etiketes, o patvirtinantys dokumentai rodo, kad vežamos žemès ūkio mašinos arba maisto produktai. Dokumentai gali būti padirbti ir rodyti, kad ginklų siunta yra skirta šaliai $x$, nors galiausiai ji atsiduria šalyje $y$.

Arba, pasinaudodami kai kuriais abejotinos reputacijos asmenimis iš plataus valstybės pareigūnų tinklo, ginklų prekybos tarpininkai gali ,itikinti“vieną ar kitą korumpuotą valstybės pareigūną parūpinti dokumentus, kurie iš esmès nèra padirbti, bet rodo „netiesa““.

$X$ šalies vyriausybès narys arba valstybės tarnautojas gali būti išdavęs užsakymo dokumentą, tarptautinio importo pažymejjimą, krovinio pristatymą patvirtinantị „kvitą“ arba pažymèjimą, leidžiantị pervežti krovinį, nors siunta pakeliui ị šalị $y$ galbūt niekada nebus vežama per šali $x$.

Tokie neteisèti vežimai pastaraisiais metais vis labiau traukia pasaulio dèmesị. Tai patvirtina pasirengimas ir siūlymai, pateikti $2001 \mathrm{~m}$. Jungtinių Tautų konferencijoje „Neteisèta prekyba šaulių ir lengvaisiais ginklais visais jos aspektais“. Regioniniu lygmeniu ES inicijavo ịvairius Bendruosius veiksmus ir nuolat tobulina Ginklu eksporto elgesio kodeksa ${ }^{10}$. Nuo 1990-ujų vidurio daug valstybių aktyviai rengia nacionalinių ịstatymų pataisas, kad galètų sugriežtinti ginklų eksporto ir importo kontrolę. Šalys kelia didesnius reikalavimus išduodant licencijas ir leidimus gabenti ginklus, atliekami kruopštesni patikrinimai iki ir po pervežimų, reikalaujama tikslesnių dokumentų, o kai kuriose šalyse - kad tarpininkai būtų registruoti ir turètų

\footnotetext{
${ }_{9}$ Wood B. \& Peleman J., „Making the Deal and Moving the Goods: The Role of Brokers and Shippers“, Lumpe L., ed., Running Guns: The Global Black Market in Small Arms, London: Zed Books, 2000, p. 130.

${ }^{10}$ Pvz., 1990-uju pabaigoje Europos Sajunga pradejo igyvendinti Kovos su neleistinu iprastiniu ginklu gabenimu programa (1997 m. birželio mėn.), Ginklų eksporto elgesio kodeksa (1998 m. birželio mèn.) ir dokumento Bendrieji veiksmai dèl Europos Sajungos indelio, užkertant kelia šauliu ir lengvuju ginklų kaupimui ir platinimui (1998 m. gruodžio mèn.) nuostatas, taip pat Veiksmu plana, siekiant užkirsti kelia ir panaikinti bet kokia neteisèta prekyba šauliu ir lengvaisiais ginklais (2000 m.).
} 
licenciją kiekvienam atskiram pervežimui, jei jie jame dalyvauja. Žinoma, tai nesustabdè neteisèto ginklų gabenimo, bet pasauliniai, regioniniai ir individualūs šalių veiksmai yra labiau derinami, o ịstatymų ir kontrolès procedūrų spragos šalinamos.

Reikmę šalinti spragas ir užtikrinti šalių įstatymų ir pasaulinio bei regioninio embargo taikymo skaidrumą, siekiant veiksmingai riboti ginklų prekybos tarpininkų, įsitraukusių i nelegalų karinès ịrangos gabenimą, veiklą ar padèti juos teisiškai persekioti, iliustruoja Jurijus Borisovas ir Kaune esanti jo firma „Avia Baltika“, kuri parduoda ir remontuoja sraigtasparnius. Lietuvos valdžia atliko keletą šios bendrovės veiklos, pvz., sandėrių su Sudanu ir Bangladešu, tyrimų, bet firma nebuvo patraukta atsakomybẻn už karinès įrangos nelegalų gabenimą ar kontrabandą į šias valstybes. Borisovas tvirtino, kad šie tyrimai buvo politizuoti, ir pareikalavo, jog būtų tiriama korupcinè „Helisotos“, vienos iš jo pagrindinių konkurenčių, su kuria dẻl tariamai korumpuotų veiksmų buvo sudaryta sutartis aprūpinti Lietuvos kariuomenę, veikla ${ }^{11}$. Nors kai kurie Lietuvos analitikai sutinka, kad Lietuvos kariniai pirkimai turètų būti skaidresni ${ }^{12}$, neabejotina, jog daug politologų, komentatorių ir elito atstovų mielai priimtų nepatrauklią Borisovo charakteristiką, kurią savo pranešime Seimui 2003 m. spalio mèn. pabaigoje pateikè buvęs Lietuvos saugumo tarnybos vadas Mečys Laurinkus ${ }^{13}$.

Nors būta ir tariamų kaltinimų, kad Borisovas pasinaudojo ar ketino pasinaudoti Lietuvos valstybės pareigūnais, kurie sąmoningai ar nesąmoningai padètų kontrabanda pervežti karinę įrangą ị šalis, kurioms taikomas tarptautinis embargas, pvz., Iraką, Libiją ir Sudaną, jis dar nenuteistas už ginklų kontrabandą. Jis pripažino, kad $2001 \mathrm{~m}$. padëjo tiekti sraigtasparnius Mi-8T Sudanui, bet 2003 m. kovo mèn. Lietuvos Seimo Laikinasis komitetas prièmė nutarimą, kad šie veiksmai nepažeidè tuo metu galiojusių Lietuvos įstatymų ${ }^{14}$. Užsienio reikalų ministerija nepatvirtino „Avia Baltikos“ licencijos eksportuoti sraigtasparnius Mi-8T į Sudaną prašymo, o Laikinasis komitetas pareiškè, kad toks eksportas prieštarautu Europos Sajungos embargo ir sankcijų principams, bet ši veikla $2001 \mathrm{~m}$. Lietuvoje nebuvo nelegali ${ }^{15}$. Borisovas vis dar nèra apkaltintas Lietuvos įstatymų pažeidimu, nepaisant to, kad jis padejo siųsti dvigubos paskirties sraigtasparnius ị Sudaną, kur jie galëjo būti panaudoti žmogaus teisėms pažeisti. Tas faktas, kad buvo svarstoma prekeivio ginklais kandidatūra ị Lietuvos prezidento patarèjo saugumo klausimais postą, kelia susirūpinimą, bet vèlgi nebūtinai tai yra neteisèta. Kaip tik dẻl šių priežasčių du toliau aprašomi atvejai turètų būti laikomi svarbiais, nors aptariamas nelegalus ginklų gabenimas vyko 1990-ujjų viduryje. Jie išlieka svarbūs, kadangi vaidmuo, kurị suvaidino tarpininkai, nelegaliai gabendami karinę įrangą ir ginklus neteisètiems tiesioginiams naudotojams, dar neišsamiai išnagrinètas, o patraukimo baudžiamojon atsakomybėn atvejų yra dar mažiau.

\footnotetext{
${ }^{11}$ „Laisvas laikraštis“ interview with Yuri Borisov“, Laisvas laikraštis, 2004 vasario 5 d., http:// www.laisvaslaikrastis.lt/EN, 20050113.

${ }^{12}$ Gricius A. \& Paulauskas K., (5 išnaša). p. 247.

${ }^{13} \mathrm{Aišku}, \mathrm{kad}$ šis tariamai slaptas Lietuvos saugumo tarnybos memorandumas, skirtas Seimo komisijai, tapo žinomas, nes po kelių dienų jo ištraukos pasirodẻ Lietuvos dienraščiuose Respublika ir Lietuvos rytas.

${ }^{14}$ „Avia Baltika accounts frozen by prosecutors“, The Baltic Times, 2003 m. gruodžio 11-17 d., www.baltictimes.com, 20050113.

${ }^{15}$ Amnesty International, Arming the perpetrators of grave abuse in Darfur, AI Index: AFR 54/139/ 2004,16 11 2004, http://web.amnesty.org/library/Index/ENGAFR541392004, 20050113.
} 


\section{Tarpininkaujantys baltai ir susirūpinimas dèl neteisèto ginklų gabenimo}

Šioje dalyje aš pateiksiu du atvejus, kai buvo nustatyta, kad Baltijos valstybiu piliečiai dalyvavo tarpininkaujant ir bandant nukreipti iš pažiūros teisètas ginklų siuntas tiesioginiams naudotojams, kuriems paskelbtas Jungtinių Tautų embargas, ir organizuotoms nusikaltèlių grupuotėms. Po šių atvejų bus pateiktos bendresnio pobūdžio problemos, susijusios su tarpininkavimu ir neteisètu gabenimu per Baltijos valstybes.

\subsection{Lietuvos tarpininkai ir branduoliniai ginklai, skirti Kolumbijai}

Pirmasis aptariamas atvejis buvo išsamiai nagrinètas kituose paskelbtuose straipsniuose apie tarpininkavimą prekiaujant ginklais ${ }^{16}$, bet tinka potencialiam pavojui, kuri kelia tarpininkai, parodyti.

1995 m. du Lietuvos piliečiai, veikiantys kaip Bulgarijos ginklų firmos „Armimex“ tarpininkai, buvo sulaikyti per Jungtinių Valstijų slaptą operaciją po to, kai sékmingai pademonstravo savo sugebèjimus neteisètai gabenti ginklus. Aleksandras Darichevas (taip pat žinomas kaip Daricevas) ir Aleksandras Pogrebzskis (taip pat žinomas kaip Pogrebovskis, Pogrebeshkis) manè, kad jie tiekia ginklus Kolumbijos narkotikų karteliui, bet iš tikrujų jais aprūpino Jungtinių Valstijų muitinès agentus. Visiems prieinamos šio slapto plano detalès aiškiai rodo, kokiu būdu ginklų prekybos tarpininkai veikia iš i̇vairių vietų, panaudoja korumpuotus pareigūnus, fiktyvias bendroves, patogių šalių vẻliavas ir aplinkinius maršrutus, kur silpna muitų ir pasienio kontrolè, kad aprūpintų „,nepageidaujamus tiesioginius naudotojus“.

Pasak Woodo ir Pelemano, Darichevui ir Pogrebzskiui pavyko gauti iš Lietuvos Respublikos krašto apsaugos ministerijos tiesioginio naudotojo pažymėjimą, rodantị, kad ji yra raketų sistemos, kurią turèjo pristatyti Bulgarijos firma „Armimex“, pirkejja. Buvo tvirtinama, kad Lietuvos Respublikos krašto apsaugos ministerija išduotų suklastotą gavimo raštą net tada, jei ši sistema būtų siunčiama kokiam nors kipriečiui priklausančiu laivu, plaukiančiu iš Lietuvos ị Puerto Riką.

Pakeliui i Puerto Riką laivas paèmė ginklų sistemą iš Bulgarijos, kur ji buvo paslèpta tarp mašinų, leidžiamų eksportuoti į Puerto Riką, děžių. Nors Darichevas ir Pogrebzskis buvo nuteisti už kontrabandą, pinigų plovimą ir sąmokslą, jiems buvo skirti tik ketveri metai kalèti ${ }^{17}$. Tačiau jų veikla, be abejonès, padèjo parodyti, kad reikia kontroliuoti ginklų prekybos tarpininkus, ir 1996 m. Jungtinių Valstijų Kongresas prièmė JAV ginklų eksporto kontrolès akto pataisą, reikalaujančią visus Jungtinių Valstijų piliečius ir užsieniečius, gyvenančius arba turinčius verslą Jungtinèse Valstijose, registruotis ir įsigyti ginklų prekybos tarpininko licencijas.

\footnotetext{
${ }^{16}$ Žr., pvz.: Wood B. \& Peleman J., "Chapter 8: The USA: Getting Around the Toughest Law", The Arms Fixers: Controlling the Brokers and Shipping Agents, 1999, http://www.nisat.org/default.asp?pa$\mathrm{ge}=$ publications/pub_videos.htm, 20040526 .

${ }_{17}$ Visą šio kaltinamojo akto tekstą galima rasti PBS interneto puslapyje http://www.pbs.org/wgbh/ pages/frontline/shows/russia/scenario/indictment.html, 20020526.
} 


\subsection{Baltijos ginklụ prekybos tarpininkụ gaujos išsklaidymas}

Antruoju aprašomu atveju kalbama apie buvusi Latvijos pulkininką, įtariamą nelegaliu ginklų gabenimu į valstybes, kurioms paskelbtas Jungtinių Tautų embargas, ir organizuotoms nusikaltèlių grupuotèms. Aš esu smulkiau išnagrinèjęs ši atveji kitur, labiau pabrèždamas dalyvavusių Lenkijos bendrovių vaidmenį, todèl neketinu jo plačiau čia aptarti ${ }^{18}$.

Istorija prasideda $1992 \mathrm{~m}$. pavasarị, kai atkurtoji Latvijos nacionalinė armija gavo iš Lenkijos perteklinių karinių medžiagų „labdarą“. Pervežimas nebuvo labai pelningas, bet užmegzti ryšiai nutiesẻ kelią daugeliui sẻkmingų neteisètų ginklų gabenimo ir perdavimo i ‘ „nepageidaujamų tiesioginių naudotojų“ rankas operacijų.

Pirmasis žinomas neteisèto gabenimo atvejis galètų atrodyti kaip klasikinis korumpuoto pareigūno, rengiančio suklastotas ginklų užsakymų deklaracijas, pavyzdys. Janis tariamai pasiuntė lenkų i̇monei „Cenrex“ $2 \mathrm{mln}$. JAV dolerių vertès ginklu ir šaudmenų, kuriuos eksportuoti iš Lenkijos ị Latviją leidimas buvo, kaip ir dera, suteiktas, užsakymą. $1992 \mathrm{~m}$. birželio mèn. laivas, gabenantis $2 \mathrm{mln}$. JAV doleriu vertės ginklų ir šaudmenų krovinị, atplaukè į Latvijos uostą Liepojoje. Tačiau tik 50 tūkst. JAV dolerių vertès automatų AK-47 ir šaudmenų buvo iškrauta ir vẻliau perkelta ị laivą netoli Somalio, valstybès, kuriai tuo metu buvo taikomas Jungtinių Tautu Saugumo Tarybos ginklų embargas, pakrantès ${ }^{19}$.

Metodas, panaudotas ginklams neteisètai gabenti ị Somali, žinomas kaip „,nepadengtasis užsakymas“. Šis terminas vartojamas, kai importuotojas parengia užsakymą didesniam ginklų kiekiui negu užregistruojama gaunant. Todèl gali būti gana didelis skirtumas tarp to ginklų skaičiaus, kurị importuotojas gauna, ir to, kurị institucija, atsakinga už importo kontrolę, mano, kad ji yra gavusi.

1992 m. rugsèjo mèn. pulkininkas Janis vèl padejo „Cenrex“ direktoriui neteisètai gabenti ginklus ị kitą šalị, Kroatiją, kuriai buvo paskelbtas Jungtinių Tautų Saugumo Tarybos embargas. Buvo pateiktas Latvijos 1,3 mln. JAV dolerių vertès ginklų užsakymas ir gautas leidimas juos eksportuoti iš Lenkijos. Gabenantis ginklus laivas Latvijoje paliko tik 50 tūkst. JAV dolerių vertès krovinị prieš atvykdamas ị Kroatijos Rijekos uostą. 1993 m. Janis buvo atleistas iš einamų pareigų Latvijos krašto apsaugos ministerijoje. Kaltinimai jam dèl „nepadengtuju užsakymu“ arba jo vaidmens neteisètai gabenant ginklus į valstybes, kurioms paskelbtas Jungtinių Tautu Saugumo Tarybos embargas, tuo metu nebuvo pareikšti. Vèliau jị konsultantu įdarbino Latvijoje veikianti įmonè „Arnex“, kuri tiekè ginklus daugeliui Latvijos vyriausybès institucijų.

Neilgai trukus Janis dar kartą ėmėsi padėti savo lenkų ryšiu tarpininkams neteisètai gabenti ginklus per Latviją. Tačiau šį kartą gabenantys ginklus laivai netgi neužsukdavo į Latviją. Buvo manoma, kad ginklai buvo pakeisti maisto prekių kroviniu jūroje.

\footnotetext{
${ }^{18}$ Išsamesnis aprašymas: Holtom P., Arms Transit in the Baltic Region, London: Saferworld, 2003, p. 64-68.

${ }_{19}$ Šis atvejis minimas Ekspertu grupes, paskirtos pagal Saugumo Tarybos rezoliucijos (2002 m.) dèl Somalio pirmaji paragrafa, ataskaitoje.
} 
Taigi laivai, gabenantys makaronų, miltų ar kitų maisto produktų krovinius, atplaukdavo į Latvijos uostus, o gabenantys ginklus buvo iškraunami Estijos Miduranos žvejybos uoste. Pasak pranešimų, 1990-ųjų viduryje buvo atlikti keturi tokie nelegalūs pervežimai. Kiekvieną siuntą sudarè TT pistoletai, koviniai šautuvai ir šaudmenys, kurių bendra verté, kaip manoma, buvo apie 640 tūkst. JAV dolerių. Tačiau šios siuntos skyrèsi nuo ankstesniujjų Janio pervežtujų tuo, kad buvo gabenamos ne į šalis, kurioms buvo taikomas Jungtinių Tautų Saugumo Tarybos paskelbtas embargas, bet Estijos prekiautojams ginklais, itariamiems juos parduodant organizuotoms nusikaltèlių grupuotems visoje Europoje. Be to, priešingai negu ankstesniu neteisètų pervežimų atvejais, būta kažkokių sutrikimų. Tai leido įstatymų vykdymo priežiūros ir saugumo tarnyboms Estijoje, Latvijoje ir Lenkijoje surinkti pakankamai įrodymų, kad asmenys, įsipainioję į šiuos nelegalius vežimus, būtu patraukti baudžiamojon atsakomybèn.

1996 m. vieno ginklus gabenančių laivų kapitonas atsisakẻ perduoti savo krovinị jūroje ir, dideliam Janio nusivylimui, atvyko ị Rygą su vis dar laive esančiu kroviniu. Stengdamasis vykdyti savo „sutartį“, jis įvardijo ginklus kaip maisto produktus ir išsiunte juos sunkvežimiu per Latvijos-Estijos sieną. Ginklai buvo susekti. Estijos saugumo tarnyboms susisiekus su savo kolegomis Latvijoje ir Lenkijoje, buvo pradètas tarptautinis tyrimas. $1997 \mathrm{~m}$. pradètas baudžiamasis procesas, kuriame „Arnex" atstovai buvo kaltinami dèl ginklų tiekimo Somaliui ir Kroatijai, šalims, kurioms buvo paskelbtas Jungtinių Tautų embargas. Nelegalaus ginklų tiekimo Estijos ginklu prekiautojams atvejai taip pat buvo tiriami ${ }^{20} .2000 \mathrm{~m}$. gegužès mèn. trims Latvijos piliečiams iškelta baudžiamoji byla buvo nusiųsta Generalinei prokuratūrai. Iškelta Janiui byla buvo nutraukta dèl senaties, o kitiems dviem teisiamiesiems buvo pareikšti kaltinimai dẻl ginklų kontrabandos 2001 metais. Abi šios bylos ne tik suteikia mums informacijos apie metodus, kurie naudojami nelegaliai gabenant ginklus, bet taip pat parodo, kokia kebli ir prieštaringa padètis susidaro po to, kai ginklu prekybos tarpininkai, turintys ryšių valstybės institucijose, yra sulaikomi neteisėtai gabenantys ginklus. Praejjo beveik dešimtmetis, kai pradètas nelegalaus ginklų gabenimo (žinomo) iš dalies sẻkmingas teisminis persekiojimas.

Šie du atvejai rodo, kodèl ginklų prekybos tarpininkų veikla ir nelegalus ginklų gabenimas kelia susirūpinimą. Būtume labai patenkinti savimi, kad patikètume, jog tokiems atvejams tinka etiketė ,ankstyvojo pereinamojo laikotarpio patirtis“. Lieka susirūpinimas dèl Baltijos valstybių administracinio pajëgumo apsisaugoti nuo nelegalaus ginklų gabenimo pačiose šalyse ir aplink jas, korumpuotos veiklos, painiavos ,pilkujų zonų“ ịstatymuose ir politinių subtilybių tiriant ir traukiant baudžiamojon atsakomybėn pavienius asmenis ar bendroves už tarpininkavimą ar kontrabandą, jei tai susiję su valstybès pareigūnais.

Be šių atvejų, Estija, Latvija ir Lietuva taip pat aprūpindavo ginklu prekybos tarpininkus ir prekiautojus ginklais priemonėmis, leidžiančiomis neteisètai gabenti krovinius oru ir jūra. Baltijos valstybių jūrų ir oro uostai, kaip potencialūs nelegalaus ginklų gabenimo punktai, taip pat kelia susirūpinimą. Daugelyje pastarojo meto pranešimų pažymima, kad krovinių, gabenamų per Talino, Klaipèdos, Rygos ir Ventspi-

${ }^{20}$ „Latvian firm did break arms embargo on Somalia as UN claims“, Neatkariga Rita Avize, 200207 19 , http://www.nisat.org/default.asp?page=/search.asp, 20040526. 
lio uostus, apyvartos apimtis jau savaime yra didele $\dot{e}^{21}$, tačiau dabar vykstančios plètros ir didejjančios krovinių gabenimo konteineriais konkurencijos sąlygomis atsiranda ịtarimų, jog šie uostai gali būti naudojami ginklų kontrabandai ${ }^{22}$.

Poreikis stiprinti kontrolę, siekiant neleisti neteisètai gabenti ginklų ir kitų strateginių prekių kertant pagrindinius tranzito ir krovinių pervežimo centrus, pradeda susilaukti daugiau tarptautinio dèmesio ${ }^{23}$. Viena iš tokių priemonių yra JAV finansuojamos masinio naikinimo ginklo ir duomenų detekcijos sistemos ịrengimas tarptautiniame Vilniaus oro uoste, rodantis susirūpinimą dèl to, kad Baltijos valstybès naudojamos nelegaliai gabenant ginklus. Tas faktas, kad $2003 \mathrm{~m}$. Lietuvos valstybẻ pakeitè „Helisotos“ aptarnaujamo sraigtasparnio, skrendančio į Jungtinius Arabu Emyratus, maršrutą taip, kad šis neužsuktų i Sudaną, rodo, jog dedamos pastangos apriboti neleistino ginklu gabenimo galimybes ${ }^{24}$. Tai, kad Rygos oro uoste Latvijos muitinès pareigūnai $2003 \mathrm{~m}$. rugpjūčio mèn. išaiškino lèktuvų ir oro gynybos sistemų krovini, kuris turejjo būti gabenamas ị Iraną iš Rusijos ir pagal dokumentus buvo nurodytas kaip statybos ir žemès ūkio mašinų dalys, taip pat galima laikyti perversmu kovoje su ginklų kontrabanda ${ }^{25}$. Bet kokių gi priemoniu ęmèsi ir kaip reagavo Estijos, Latvijos ir Lietuvos vyriausybès, siekdamos kontroliuoti tarpininkavimą ir sukliudyti nelegaliai gabenti ginklus?

\section{Ginklų kontrolè, tarptautinis bendradarbiavimas ir problemos}

Nors visos trys Baltijos valstybès įvedè kontrolę tam tikriems ginklų, strateginių ir dvigubos paskirties prekių kroviniams, gabenamiems tranzitu per jų teritorijas, nuo 1990-ųjų pradžios šių šalių įstatymuose, reglamentuojančiuose importo, eksporto ir tranzito kontrolę, padaryta daug pataisų ir netgi buvo priimta naujų įstatymų. Naujausi Estijos, Latvijos ir Lietuvos ịstatymai dėl ginklų ir strateginės bei dvigubos paskirties prekių eksporto, importo ir tranzito kontrolès, taip pat ginklų, strateginių prekių ir šalių, kurioms taikoma kontrole, sąrašai tiksliai atitinka Europos Sajungos bendruosius veiksmus, direktyvas ir Ginklų eksporto elgesio kodeksą. Be to, Estija, Latvija ir Lietuva viešai parème Europos saugumo ir bendradarbiavimo organizacijos dokumentą dèl šaulių ir lengvụjų ginklų bei pasirašė Jungtinių Tautų Konvencijos prieš tarptautinį organizuotą nusikalstamumą Protokolą prieš neteisètą šaunamuju ų ginklų, jų dalių ir komponentų bei šaudmenų gamybą ir prekybą jais.

${ }^{21}$ Žr., pvz.: Brodin A., red., Russian Transit Trade in the Baltic Sea Region, Centre of European Research, Goteborg University, 2002; Laurila J., „Determinants of transit transports between the European Union and Russia“, BOFIT Online, 1, 2002, p. 26, http://www.bof.fi/bofit/eng/7online/ abs /pdf/bon0102.pdf, 20040526.

${ }^{22}$ Baiminamasi, kad konteineriai yra ypač naudinga priemonè neteisètoms ginklų siuntoms gabenti, žr.: The Economist, 2002 m. balandžio 4 d., http://www.economist.com/, 200305 10; Holtom P., (9 išnaša) p. $16-19$.

${ }^{23}$ Žr., pvz., „Emerging Issue: Transit and Transshipment Controls“, NIS Export Control Observer, 200304 04, p. 18, http://cns.miis.edu/pubs/nisexcon/pdfs/ob_0304e.pdf, 20040526.

${ }^{24}$ Amnesty International, (15 išnaša).

${ }^{25}$ Interfax naujienų agentūra, Latvija pradeda baudžiamaja byla, susijusia su ginklu, gabenamu $i$ Irana, užgrobimu, $2003 \mathrm{~m}$. rugpjūčio $29 \mathrm{~d}$. 
Šio straipsnio problemų nagrinèjimo aspektu visos trys valstybès apibrèžè tarpininkavimo veiklą savo ịstatymuose ir reikalauja, kad tokia veikla užsiimantys šių šalių piliečiai ir gyventojai turètų licencijas ir būtų tikrinami bei kontroliuojami. $2004 \mathrm{~m}$. jos buvo tarp 25 pasaulio valstybių, turinčiu istatymus, kurie kontroliuoja ginklų prekybos tarpininkų veiklą, ir padejo padidinti Europos Sajungos valstybių narių, prièmusių svarbiausius šios srities įstatymus, skaičių nuo 8 iki 16.

Nors buvo teigiama, kad tarpininkavimo kontrole vykdoma Estijoje jau nuo $2001 \mathrm{~m} .^{26}$, įstatymai tapo daug aiškesni prièmus Estijos Respublikos strateginiu prekiu akta $(2003)^{27}$. Dabar bet kuris Estijos pilietis, susijęs su karinių prekių ịigijimu, informacijos teikimu, praktine pagalba ar fondais, skirtais sanderriui tarp dviejų trečiųjų šalių, esančių ne Estijos teritorijoje, atlikti, privalo turèti leidimą užsiimti tokia veikla, taip pat turi būti ịtrauktas į valstybinị tarpininkų registrą ir kreiptis dẻl licencijos kiekvienam sandėriui, kuriame dalyvauja, sudaryti. Todėl Estija įvedè tarpininkavimo veiklos kontrolès sistemą, kuri atitinka daug rekomendacijų, pateiktų Europos Sajungos Tarybos dokumente Tarybos bendroji pozicija dèl tarpininkavimo ginklu prekyboje kontroless $(2003 \mathrm{~m} \text {. birželio } 15 \mathrm{~d} \text {. })^{28}$.

Latvijos vadovybè teigia, jog jų tarpininkavimo veiklos kontrolès sistema funkcionuoja nuo $1997 \mathrm{~m}$., ir tai susieja su faktu, kad nuo šios datos bendrovès, priklausančios Latvijos piliečiams arba nuolatiniams Latvijos gyventojams, privalo tureti Latvijoje išduotas tranzito licencijas, jeigu jos dalyvauja gabenant strategines prekes iš vienos užsienio šalies i kitą per trečiają šali, netgi tuo atveju, jei tranzito krovinys neįvežamas ị Latvijos teritoriją ar neišvežamas iš jos ${ }^{29}$. Tačiau buvo neaišku, ar ši nuostata būtu taikoma eksteritorialiais atvejais, kaip yra pagal Belgijos įstatymus. Šiuo pagrindu nè viena byla nebuvo iškelta Latvijos piliečiui ar bendrovei, todèl klausimas liko teorinis. Tačiau Latvija išsaugojo daugelio metų ginklų sandèrių, ivykdytų Latvijos įmonių, îskaitant juridinius asmenis, kuriuos galima būtų pavadinti ginklu prekybos tarpininkais, duomenų bazę. Kaip ir kaimynès, Latvija neseniai, prieš stodama ị Europos Sajungą, prièmè daug ịstatymų, kurie patikslina tarpininkavimo reikalavimus, atitinkančius Bendraja poziciją dèl tarpininkavimo ginklu prekyboje kontroles $^{30}$.

Siekdama kovoti su nelegaliu ginklų gabenimu, Lietuva, dar prieš įstodama ị Europos Sajungą 2004 m., taip pat ịvedè tarpininkavimo veiklos kontrolę. Neseniai buvo priimta keletas karinès įrangos, ginklų ir šaudmenų importą, tranzitą ir eksportą reglamentuojančių îstatymų, išsamiai apibūdinančiu tarpininkavimo veiklą, reikalavimus norintiems gauti leidimus ir licencijas bei registrų sudarymo reikalavimus ${ }^{31}$, ir taip sukurta tarpininkavimo kontrolès sistema anksčiau nei tą padarè „senosios“ Europos Sajungos valstybės narès Graikija, Liuksemburgas ir Jungtinè Karalystė.

\footnotetext{
${ }^{26}$ Estijos Vyriausybės įsakas Nr. 154 „Dèl strateginių prekių sąrašo patvirtinimo“, 20010430.

${ }^{27}$ Estijos Respublikos strateginiu prekiu aktas, galiojantis nuo 20040205.

${ }^{28}$ Europos Sajungos Tarybos bendroji pozicija dèl tarpininkavimo ginklu prekyboje kontroles, 2003/ 468/CFSP, 20030623.

${ }^{29}$ Latvijos ministrų kabineto patvirtinti Strateginiu prekiu kontroles nuostatai, 19971216.

${ }^{30}$ Ginklu apyvartos istatymas, galiojantis nuo 20030101 ; Strateginiu prekiu apyvartos istatymas, galiojantis nuo 20040105.

${ }_{31}$ Strateginiu prekiu ir technologiju importo, tranzito ir eksporto kontroles istatymo pakeitimo istatymas, patvirtintas 200202 05; Ginklų ir šaudmenų kontrolès įstatymas, galiojantis nuo 20030701.
} 
Tačiau kaip ir kitos Europos Sajungos pastangos kovojant su ginklų kontrabanda ir nelegaliu jų eksportu iš legalios rinkos ị nelegalią, Tarybos bendroji pozicija jau buvo kritikuojama dèl savo negriežtų (minimalių) standartų. Užuot raginant perimti geriausią patirtį, kuri jau išdèstyta kai kurių Europos Sajungos valstybių narių, tokių kaip Belgija, Suomija ir Vokietija, istatymuose ir kituose teisès aktuose, valstybès kviečiamos ją , apsvarstyti“ arba prašomos ,galbūt“ siūlyti tam tikras priemones. Vis dellto, nepaisant nuogąstavimų, kad Europos Sajungos Taryba neskyré pakankamai dèmesio su tarpininkavimo veikla ir eksteritorialumu susijusios kontrolès stiprinimui ir kad vis dar nèra „standartinio modelio“, reglamentuojančio ginklų prekybos tarpininkų ir jų sandèrių licencijavimo, kontrolès ir registravimo tvarką ${ }^{32}$, Baltijos valstybės savo eksporto, importo ir tranzito kontrolès įstatymuose numatè daug griežtesnius reikalavimus tarpininkavimo veiklai, nei yra taikomi kitų ES valstybių narių.

Deja, tai dar nereiškia, kad geranoriški ịstatymai bus ịgyvendinti, jog jų bus laikomasi, t. y. viskas vyks savaime. Pavyzdžiui, per penkerius metus, priemus JAV Ginklu eksporto kontrolès akto pataisą dèl tarpininkavimo ginklu prekyboje, nè vienas ginklų prekybos tarpininkas nebuvo pagal ją patrauktas baudžiamojon atsakomybė $^{33}$, nors kai kas teigè, kad pataisos, kaip atgrasinimo priemonès, veikimas tolygus anekdotui ${ }^{34}$. JAV ginklų prekybos tarpininkų kontrolè dar nebuvo patikrinta. Lenkų ekspertai yra būgštavę dèl ginklų kontrolès, sakydami, kad nors įstatymų leidèjai gali teisètai didžiuotis savo ịstatymais, numatančiais ginklų prekybos tarpininkų kontrolę ir šalinančiais spragas, anksčiau neleidusias patraukti baudžiamojon atsakomybėn asmenų, dalyvaujančių neteisètose ginklų gabenimo operacijose, Lenkija nėra pakankamai pajègi užtikrinti, kad šie įstatymai būtų vykdomi. Ir Latvijos pareigūnai pareiške esą susirūpinę dėl Latvijos galimybių priversti vykdyti reikalavimą, kad latviams priklausančios įmonès arba juridiniai asmenys užsienyje turètų licencijas ir leidimus, jeigu jie dalyvauja pervežant ginklus ne per Latvijos sieną. Nepaisant problemų, susijusių su visų trijų valstybių galimybėmis, visa tai turi užkirsti kelią neteisètai veiklai: neleisti gabenti ginklų per šių šalių oro ir jūrų uostus bei sausumos sienų perejimo punktus. Europos Sajungai ir Europos Tarybos Valstybių antikorupcinei grupei (GRECO) ịvertinus Estijos, Latvijos ir Lietuvos teisines, įstatymų igyvendinimo priežiūros, pasienio ir muitinès tarnybas, buvo atkreiptas demesys ị kai kurias bendras problemas, susijusias su korupcija, patirtimi ir ištekliais, kurios galètų turèti įtakos šių valstybių galimybėms atskleidžiant planuojamas neteisèto gabenimo operacijas bei tarpininkavimo prekiaujant ginklais veiklą.

Dalis šių bendrų problemų ir trūkumų, susijusių su ginklų kontrole ir igyvendinamų i̊statymų priežiūra, muitinès ir pasienio ịstatymais, yra aktyviai sprendžiami panaudojant tarptautinių Europos Sajungos fondų paramą, taip pat dvišalius bei daugiašalius bendradarbiavimo su Europos Sajungos valstybėmis narèmis, JAV, Norve-

\footnotetext{
${ }^{32}$ Dèl išsamesnès Bendrijos pozicijos dèl tarpininkavimo ginklu prekyboje kontrolès kritikos žr.: Amnesty International, Undermining Global Security. The European Union's Arms Exports, London: Amnesty International, May 2004; Anders H., Controlling Arms Brokering. Next Steps for EU Member States, Brussels: GRIP, January 2004, http://www.grip.org, 200405 26. Andersas taip pat pateikia naudingą tarpininkavimo įstatymų, galiojusių iki $2004 \mathrm{~m}$. ES plètros, apžvalgą.

${ }^{33}$ Austin K., (2 išnaša), p. 207.

${ }^{34}$ Amnesty International, (32 išnaša), p. 29.
} 
gija bei kitomis šalimis projektus. Estija, Latvija ir Lietuva yra sudariusios keletą tarpusavio bendradarbiavimo sutarčių, taip pat pasirašiusios susitarimų su Baltijos jūros regiono valstybių kaimynėmis ir kitomis Europos Sajungos valstybėmis dèl kovos su organizuotu nusikalstamumu, dèl tinkamiausio praktinio muitinès, pasienio ir kitu įstatymų priežiūros, darbuotojų mokymo bei ịrangos šioms tarnyboms i̊sigijimo ${ }^{35}$. Tačiau siūlomos pagalbos igyvendinant tarpininkavimo kontrolę dar nematyti. Daug nevyriausybinių organizacijų remiamų pranešimų dabar aktyviai akcentuoja tą faktą, kad buvo skiriama nepakankamai dèmesio eksporto kontrolès sistemoms tų valstybių, kurios sieké Europos Sajungos narystės 2004 m., ir kad dabar joms reikia suteikti daugiau techninès ir finansinès paramos ${ }^{36}$. Tai grindžiama nuomone, jog visos Europos Sajungos kontrolès sistemos stiprumas yra tolygus jos silpniausios grandies stiprumui, o daug griežtų eksporto ir tarpininkavimo kontrolès metodų šalininkų mano, kad naujosios valstybès narès dèl savo administracinio pajègumo problemų yra silpnosios grandys.

Žinoma, dèl tarpininkavimo veiklos kontrolès ir priemonių, trukdančių siųsti ginklus ir strategines prekes ị tarptautinę neteisètos prekybos ginklais rinką, pobūdžio kyla daugiašalio bendradarbiavimo poreikis. Tarptautiniai neplatinimo režimai, tokie kaip Australijos grupé (AG), Raketų technologijų kontrolès režimas (MTCR), Branduolinio neplatinimo sutartis (NPT), Branduolinių tiekèjų grupé (NSG) ir Wassenaaro susitarimas (WA), buvo sukurti siekiant efektyviau priešintis ginkluotès platinimui, sudarant galimybę dalyvauti forumuose, kuriuose keičiamasi informacija apie medžiagas, prekes ir abejotinos reputacijos tiesioginius naudotojus. Tačiau paaiškejjo, kad tokios organizacijos dẻl narystės linkusios apsiriboti tomis valstybėmis, kuriose gyvena tam tikrų prekių ir medžiagų gamintojai ir tiekèjai. Todèl neatrodo, kad Baltijos valstybės turètų pagrindą prisijungti prie šių režimų.

Nepaisant to, ir toliau pabrèžiama, kad narystė šiuos režimus taikančiose organizacijose yra vienas iš svarbiausių Estijos, Latvijos ir Lietuvos užsienio ir saugumo politikos prioritetų. Taigi Baltijos valstybės reikalauja, kad būtų reformuojami dvidešimtojo amžiaus ginkluotès neplatinimo režimai, jog jos galètų sẻkmingai ịveikti dvidešimt pirmojo amžiaus iššūkius. Pavyzdžiui, Estija ir Lietuva 2004 m. gegužès mèn. buvo priimtos į Branduolinių tiekejjų grupę. Estijos eksporto kontrolès specialistas Toomas Raba pateikè įikinamus argumentus, kad mažos tranzito valstybės, tokios kaip Estija, būtų priimtos ị tarptautinių režimų grupes netgi tuo atveju, jei jos nèra kontroliuojamų prekių ir medžiagų gamintojos ar tiekejos, kadangi :

- tranzito valstybès privalo dalyvauti pasikeitimo informacija procesuose, jei jos tikisi garantijos, kad prekès, galinčios kelti grèsmę tarptautiniam saugumui, nèra neteisètai gabenamos. Tais atvejais, kai vadinamosios „dvigubos paskirties prekès“, pavyzdžiui, prekès, kurios gali būti naudojamos ne tik branduoliniu ginklų gamyboje, bet taip pat ir kitiems ,civiliniams“ tikslams, yra gabenamos per Baltijos jūrą arba Baltijos šalių tarpininkas dalyvauja gabenant tokias medžiagas, tada, neturẻdamos galimybès naudotis informacija, kuri skirta tik režimo grupès nariams, Estija, Latvija

\footnotetext{
35 Žr. t. p. atitinkamą skyrių; P. Holtom, (18 išnaša)

${ }^{36}$ Amnesty International, (32 išnaša), p. 95.
} 
ir Lietuva gali duoti leidimą gabenti šias medžiagas tiesioginiam naudotojui, kuris neturètų gauti tokių medžiagų;

- mažos valstybès turi ribotus žmonių, finansinius ir intelektualinius išteklius, kad galètų kontroliuoti tiesioginius naudotojus ir tiesioginị naudojimą, todèl būtina bendradarbiauti su kitomis šalimis tikrinant krovini prieš ji pakraunant ir iškrovus ${ }^{37}$.

Raba nuomone, nors Baltijos valstybės jau bendradarbiauja ir keičiasi informacija su režimų grupių nariais, pavyzdžiui, per Baltijos jūros ir Europos Sajungos struktūras, to neužtenka, norint užtikrinti, kad Estija, Latvija ir Lietuva galètų efektyviai neleisti gabenti ar nukreipti pavojingų prekių ir medžiagų nepageidaujamiems tiesioginiams naudotojams. Žinoma, Raba pažymi, kad regioniniai bendradarbiavimo forumai, tokie kaip specialūs Baltijos/ Šiaurès valstybių susitikimai, kuriuose keičiamasi informacija, ir Europos Sajungos Iprastinių ginklų eksporto darbo grupès susitikimai yra labai svarbūs stiprinant šalies ir tarptautinę kontrolę, kadangi jie suteikia galimybę užmegzti gerus asmeninius ryšius, stiprinti pasitikejimą ir gerą valią bei siekti požiūriu panašumo, kas yra laikoma būtinais „kertiniais akmenimis“ norint efektyviai keistis informacija, susijusia su krovinio patikrinimu prieš ji pakraunant ir iškrovus, bei informacija apie tiesioginius naudotojus. Tačiau norint užkirsti kelią neteisètam gabenimui, kuris savo mastu yra potencialiai globalus, tokių geografiniu požiūriu ribotų santykių nepakanka.

Vis dèlto kaip tik regioniniai susitarimai dèl pasikeitimo informacija apie ginklų kontrolę yra galimi išeities taškai pereinant prie pasaulinès tarpininkavimo ginklų prekyboje kontrolès. Jeigu Europos Sajungai pavyks sukurti efektyvią sistemą, leidžiančią keistis informacija apie įstatymus, registruotus tarpininkus, duomenimis apie ịvykdytas ir nepavykusias operacijas, ir jeigu ji norès išplèsti tokius susitarimus įtraukdama ị juos ir trečiąsias valstybes ar valstybių grupes, tuomet galima būtų sukurti pasaulini pasikeitimo informacija tinklą. Europos Sajunga jau sèkmingai eksportavo savo Elgesio kodeksą i i narystès siekiančias ir kitas valstybes. Ar būtų įmanoma pradèti panašų procesą, susijusį su Bendraja pozicija dėl tarpininkavimo ginklų prekyboje kontrolės, kasmet papildant Elgesio kodeksą nuostatomis dèl tarpininkavimo kontrolès? Koks gi tuomet būtų Baltijos valstybių vaidmuo?

\section{Išvados}

Yra keletas veiksmų, kurių Baltijos valstybės galètų imtis atskirai arba per daugiašalius mechanizmus, noredamos padèti sutrukdyti siųsti ginklus iš teisètos ginklų rinkos ị neteisètą ir nepageidaujamiems tiesioginiams naudotojams. Baltijos valstybès ir toliau neturètų besąlygiškai pasitikèti neplatinimo režimais bei modeliais ir remti regionų ir pasaulio pastangas kovojant su neteisèta prekyba ginklais ir neteisètu jų gabenimu. Pavyzdžiui, Baltijos valstybès ,turètų aktyviai palaikyti procesą sudarant teisiškai ịpareigojančią tarptautinę prekybos ginklais sutartị “638. Daugelis

${ }^{37}$ Raba T., "Enhancing export controls in transit states", The Monitor: International Perspectives in Nonproliferation, 8 (2), 2002, p. 19-21.

${ }^{38}$ Amnesty International, (32 išnaša), p. 98. 
tarptautinių nevalstybinių organizacijų atkakliai siekia pasaulinės ginklų prekybos sistemos, kuri reikalautų didesnio skaidrumo ir atskaitingumo, licencijuoti ginklų gamybą užsienyje, registruoti ir kontroliuoti ginklų prekybos tarpininkus ir su tarpininkavimu susijusias tarnybas, geresniu ginkluotès atsargų valdymo ir naikinimo programų, aiškesnès ir griežtesnès tranzito ir krovinių vežimo kontrolès ir tarptautinès ne tik karinès įrangos, bet ir stebejjimo, kankinimo bei nematerialiujų ištekliu vežimo kontrolès, taip pat tobulesnių tiesioginės kontrolès mechanizmų ${ }^{39}$.

Bene lengviausias ir tiesiausias veiksmas, kurio turètų imtis Baltijos valstybès, - pateikti kitoms Europos Sajungos valstybèms narèms informaciją apie šiose valstybėse registruotus tarpininkus ir detales, susijusias su jų ịvykdytomis ir, svarbiausia, sužlugdytomis operacijomis. Tai parodytų, kad jos nėra silpnosios grandys, o aktyvios dalyvès, siekiančios kontroliuoti teisètą ginklų prekybą ir užkirsti kelią nelegaliam jų gabenimui. Tai galètų būti ịrodyta pateikiant „pavyzdines“ metines ataskaitas apie ginklų, karinès įrangos ir kitų strateginių bei dvigubos paskirties prekių importo, eksporto ir tranzito krovinius, kas pranoktu minimalius reikalavimus, kurie yra išdèstyti pateikiant Europos Sajungos Elgesio kodekso ginklų eksporto srityje 8-aji kriterijų (nuostatą). Tuo pat metu, nuogąstaujant dèl potencialių korupcijos atveju i̊sigyjant ginklu kariuomenei ir kitoms valstybinèms organizacijoms, reikètų dèti pastangas, kad parlamentai skirtų ypatingą dėmesį eksportui, importui ir tranzitiniam ginklų gabenimui.

Pagalbos galima būtų prašyti kitų Europos Sajungos valstybių narių parlamentų, šalių ir tarptautinių nevalstybinių organizacijų, jei suvokiama, kad parlamentarai dar neturi pakankamai žinių, jog galètų imtis tokių užduočių. Atrodo, kad šios srities žiniasklaidos skyriai taip pat pradeda domètis ginklų importu ir eksportu bei grèsmèmis, kurias kelia besidomintys nestabiliais regionais ginklų prekybos tarpininkai, o tai leidžia geriau informuoti visuomenę.

Baltijos valstybės galètų prisidèti prie tarptautinès kovos su nesąžiningais ginklų prekybos tarpininkais iškeldamos parodomają bylą, kuri remtųsi iš naujo patobulintais šalies ịstatymais. Tai bene vienas iš sudètingiausių siūlymų, pateikiamų šiose išvadose, kadangi jis reikalauja gerokai daugiau negu politine retorika ir ịstatymų leidyba. Pirma, reikia tos sẻkmès, kuri padejo Estijos, Latvijos ir Lenkijos ịstatymu igyvendinimo priežiūros organams atskleisti anksčiau aprašytą ginklų kontrabandos tinklą. Ir antra, reikès daug politinès valios ir drąsos norint iškelti bylas asmenims, tarp kurių galètų būti daug Baltijos bei kitų valstybių vyriausybių pareigūnų, ir išsklausyti jų parodymus.

${ }^{39}$ Ibidem. 